\title{
Taksonomia sprawności słuchania i mówienia w języku polskim jako ojczystym
}

\author{
A taxonomy of listening and speaking skills \\ in Polish as a native language
}

\begin{abstract}
In their article, Marta Chyb-Winnicka and Anna Tabisz present a taxonomic approach to the teaching of listening and speaking skills in lessons of Polish as a native language. The authors show that the 2017 provisions of the core curriculum for the Polish language in primary schools in Poland put special emphasis on the development of reading and writing skills. For this reason, Chyb-Winnicka and Tabisz underline the importance of teaching the two other skills, i.e., listening and speaking, and argue that taxonomic categories should be used to systematize the knowledge of these skills.
\end{abstract}

Keywords: listening skills, speaking skills, taxonomy, core curriculum, primary school

W artykule chcemy podjąć próbę usystematyzowania wiedzy na temat kształcenia sprawności słuchania i mówienia we współczesnej szkole. Na początku warto zauważyć, że „w powszechnym przekonaniu środowiska nauczycieli-polonistów szkoła miała uczyć przede wszystkim pisania i czytania, natomiast mówienie i słuchanie uznawano za kompetencje nabywane w procesie językowo-komunikacyjnej socjalizacji"’. Skoro mówienie i słuchanie są

${ }^{1}$ J. Nocoń: Diagnozowanie sprawności mówienia w perspektywie (nie tylko) egzaminu maturalnego. „Polonistyka. Innowacje” 2015, nr 1, s. 4. https://doi.org/10.14746/pi.2015.1.1.1. 
sprawnościami nabywanymi w sposób naturalny, poza szkołą, to uznano, że ich przyswojenie nie łączy się z większym wysiłkiem, w przeciwieństwie do pisania i czytania, których nauczenie się jest już pracą. Sprawności nabywane $\mathrm{w}$ procesie przyswajania ${ }^{2}$ są postrzegane jako bezwysiłkowa psychofizjologiczna reakcja na doraźną potrzebę o charakterze spontanicznym, polegająca na bezrefleksyjnym użyciu języka, które cechuje się mniejszym poczuciem odpowiedzialności za treść wypowiedzi

Termin „przyswajanie języka” odróżnia się w literaturze przedmiotu od terminu „,uczenie się języka”, który oznacza „stosowanie specjalnych zabiegów [...] w celu opanowania określonych struktur językowych"4. Nabywanie i doskonalenie kompetencji językowej i komunikacyjnej w procesie uczenia się odbywa się w warunkach laboratoryjnych, nienaturalnych, oderwanych od autentycznych sytuacji komunikacyjnych. Zachowania komunikacyjne zostają wcześniej zaplanowane przez nauczyciela i funkcjonują na lekcjach jako zadania dydaktyczne, a ich wykonanie podlega refleksji i wartościowaniu. Dochodzi zatem do swoistego treningu komunikacyjnego, którego celem jest rozwijanie i doskonalenie umiejętności porozumiewania się, nabytej już w jakimś stopniu w procesie przyswajania języka.

Założenie, że mówienie i słuchanie to sprawności, które zostały opanowane w procesie pierwotnej socjalizacji ${ }^{5}$, ma swoje skutki edukacyjne. Jak zauważa Jolanta Nocoń, „przez lata nie wypracowano stosownej metodyki, a działania edukacyjne sprowadzone były do aranżowania na lekcjach mówionych interakcji edukacyjnych (odpowiadanie na pytanie nauczyciela i ustne relacje z wykonania poleceń)" ${ }^{\prime \prime}$. Poza tym dominacja heurezy, a jeszcze częściej pogadanki heurystycznej z jej redukcyjno-instrumentalnym podejściem do rozwijania sprawności mówienia i słuchania, powoduje, że dominującą funkcją

${ }^{2}$ Proces przyswajania należy rozumieć jako spontaniczne nabywanie kompetencji językowej i komunikacyjnej głównie poprzez naśladowanie wzorców komunikacyjnych dorosłych z najbliższego otoczenia. Zob. I. Kurcz: Psychologia języka i komunikacji. Wyd. 2., nowe. Scholar, Warszawa 2005, s. 69.

${ }^{3} \mathrm{~K}$. Bakuła: Mówione $\approx$ pisane: komunikacja, język, tekst. Wydawnictwo Uniwersytetu Wrocławskiego, Wrocław 2008, s. 23.

${ }^{4}$ I. Kurcz: Psychologia języka i komunikacji..., s. 69.

${ }^{5}$ Wyróżnia się socjalizację pierwotną oraz socjalizację wtórną. Ta pierwsza zachodzi od momentu narodzin jednostki i jest etapem najbardziej intensywnej edukacji kulturowej (okres niemowlęctwa i wczesnego dzieciństwa), w tym czasie dzieci przyswajają język oraz podstawowe wzory zachowań. Socjalizacja wtórna z kolei dotyczy starszych dzieci i rozciąga się na życie dorosłe jednostki; na tym etapie w procesie socjalizacji uczestniczą szkoły, grupy rówieśnicze, organizacje, media oraz miejsca pracy. Zob. A. Giddens: Socjologia. Wyd. 1., dodruk. Thum. A. Szulżycka. Wydawnictwo Naukowe PWN, Warszawa 2004, s. 51.

6 J. Nocoń: Diagnozowanie sprawności mówienia w perspektywie (nie tylko) egzaminu maturalnego..., s. 5-6. 
wypowiedzi ustnych jest funkcja informacyjna ,z jednoczesną redukcją lub eliminacją pozostałych funkcji oraz sprowadzanie komunikacji do roli narzędzia przekazu i egzekwowania wiadomości szkolnych"7, a najistotniejszymi dla nauczycieli cechami informacji są ich merytoryczność i poprawność.

Dzisiaj można postawić tezę, iż wielu uczniów na wszystkich etapach edukacji szkolnej ma trudności ze słuchaniem ${ }^{8}$ i z mówieniem ${ }^{9}$, a podniesienie poziomu kompetencji w zakresie tych sprawności jest jednym z wyzwań edukacyjnych we współczesnej szkole. Jest to o tyle istotne, iż aktywne słuchanie i dobre, świadome mówienie warunkują zarówno szkolne funkcjonowanie uczniów (sprzyjają bowiem rozwojowi myślenia i służą uczeniu się) ${ }^{10}$, jak i ich pozaszkolne losy — są kluczowymi umiejętnościami, dzięki którym młodzi ludzie mogą osiągnąć sukces w życiu.

\section{Sprawność słuchania}

Słuchanie wypowiedzi jest skomplikowaną umiejętnością komunikacyjną, na którą składa się szereg predyspozycji, zdolności i umiejętności ${ }^{11}$ :

${ }^{7}$ D. Klus-Stańska, M. Nowicka: Sensy i bezsensy edukacji wczesnoszkolnej. Harmonia Universalis, Gdańsk 2014, s. 98.

${ }^{8}$ Zob. m.in. M.U. Chyb: Jak stucha ósmoklasista? Próba diagnozy [w druku]; Eadem: Umiejętność stuchania czwartoklasistów. Próba diagnozy. „Kształcenie Językowe” 2020, T. 18 (28), s. 39-61. https://doi.org/10.19195/1642-5782.18(28).4; Eadem: Efektywne stuchanie w języku polskim jako ojczystym - diagnoza i profilaktyka. Praca doktorska pod kierunkiem J. Nocoń. Uniwersytet Opolski. Opole 2021 [maszynopis niepublikowany].

${ }^{9}$ Zob. m.in. A. Tabisz: Czy szkoła uczy mówienia? O ustnych wypowiedziach gimnazjalistów. „Polonistyka. Innowacje” 2015, nr 1, s. 54 -69. https://doi.org/10.14746/pi.2015.1.1.5; Eadem: Lekcje mówienia - o (nie)ptynności wypowiedzi. W: Uczenie języka ojczystego w czasach ponowoczesnych. Red. A. Tabisz. [Język a Edukacja, 5]. Wydawnictwo Uniwersytetu Opolskiego, Opole 2017, s. 253-264; A. Tabisz: Czy zmierzch kultury mówienia? - o wybranych cechach ustnych wypowiedzi maturzystów. W: Istnieć w kulturze, istnieć w kulturach. Między teoria a praktyka edukacyjna. Red. A. Rypel, D. Jastrzębska-Golonka. Wydawnictwo Uniwersytetu Kazimierza Wielkiego, Bydgoszcz 2018, s. 186-202.

${ }^{10}$ Zob. D. Klus-Stańska, M. Nowicka: Sensy i bezsensy edukacji wczesnoszkolnej..., s. 101 i nast.

${ }^{11}$ Przyjmujemy, że zdolności mają charakter bardziej wrodzony (na przykład uwaga, koncentracja, pamięć), a umiejętności — nabyty (na przykład słuchanie empatyczne, korzystanie ze strategii pamięciowych); zarówno umiejętności, jak i zdolności mogą być rozwijane i doskonalone. Por. A.E. Sękowski, O. Bilyakovska: Zdolności człowieka jako wymiar psychologiczny. „Języki Obce w Szkole" 2011, nr 1, s. 18-24. Z kolei predyspozycje związane są z możliwościami człowieka do odbioru dźwięków, na przykład wiedza, doświadczenie życiowe. Por. [hasło:] predyspozycja. https://wsjp.pl/index.php?id_hasla=4874 [dostęp: 9.01.2021]. 
a) biologiczne:

- sprawny narząd słuchu;

- sprawny układ nerwowy i prawidłowo funkcjonujące struktury neurologiczne odpowiedzialne za przetwarzanie mowy;

b) poznawcze:

— szeroki zakres wiedzy uprzedniej i duże doświadczenie życiowe;

- wysoko rozwinięta zdolność planowania, wnioskowania, analizy, selekcji i hierarchizacji informacji, a także myślenia dedukcyjnego;

- rozwinięta sprawność antycypacji;

— wysoki poziom uwagi i koncentracji; rozwinięta pamięć słuchowa (krótkotrwała i długotrwała);

— znajomość strategii pamięciowych ułatwiających zapamiętanie komunikatu, umiejętność korzystania z nich;

c) językowe:

— biegła znajomość języka na wszystkich poziomach: fonologicznym (znajomość inwentarza fonemów, reguł fonetycznych i prozodycznych właściwości języka, sprawny słuch fonematyczny, fonetyczny i prozodyczny), leksykalnym (bogaty zasób słownictwa biernego), składniowym (znajomość szerokiego wachlarza struktur gramatycznych), tekstowym (znajomość reguł rządzących budową tekstów, sprawność rozumienia ich na poziomie globalnym, epizodycznym i lokalnym, umiejętność identyfikacji gatunków mowy, rozpoznawanie czynników kontekstowych, funkcji wypowiedzi, uwzględnianie ich podczas analizy tekstów na tle odpowiednich dyskursów, sprawność wykonywania działań na tekście);

— także wysoki poziom kompetencji językowej i komunikacyjnej (w tym tekstowej, gatunkowej i dyskursywnej);

d) społeczno-komunikacyjne:

- szeroki zakres wiedzy o komunikacyjnych uwarunkowaniach tekstu, znajomość obowiązków odbiorcy względem nadawcy tekstu;

— świadomość komunikacji niewerbalnej, umiejętność przypisywania znaczeń komunikatom pozajęzykowym i uwzględnianie ich podczas przetwarzania tekstu;

— znajomość rodzajów komunikatów zwrotnych i umiejętność ich nadawania, ze świadomością ich funkcji i efektów komunikacyjnych;

- świadomość barier utrudniających rozumienie komunikatów, umiejętność niwelowania tych barier;

— wysoko rozwinięta umiejętność słuchania empatycznego — otwarcie się na drugą osobę, umożliwienie jej sprawnego wypowiadania myśli12 ${ }^{12}$

12 Por. A. Paliński: Psychologiczna charakterystyka procesów stuchania i czytania $w$ języku obcym w aspekcie porównawczym. W: Sprawność słuchania i czytania w nauczaniu języków 
Ponieważ słuchanie to nie tylko odbiór wypowiedzi, lecz także umiejętność reagowania na nią, przyjmujemy, że szczegółowe sprawności percepcyjne mają dwa aspekty:

— receptywny - polegający na odbiorze wypowiedzi, jej analizie, interpretacji i ocenie;

- produktywny - polegający na tym, że wszelkie działania niewerbalne/ werbalne (ustne lub pisemne) powstałe na skutek słuchanego tekstu sprowadzają się do jego przekształcenia, stworzenia na jego podstawie innej wypowiedzi lub wyrażenia własnych emocji wywołanych przez percepcję słuchową za pomocą sygnałów niewerbalnych (na przykład drama, pantomima) ${ }^{13}$.

Sprawności receptywne i produktywne mogą być związane z odbiorem wypowiedzi na poziomie:

— globalnym — na przykład rozumienie sensu, tematu, głównej myśli tekstu;

- lokalnym - na przykład rozumienie jednostek niższego rzędu stanowiących budulec całego tekstu, rozumienie pojedynczych zdań, wypowiedzeń, słów ${ }^{14}$.

Skoro mamy świadomość złożoności i stopnia trudności słuchowego odbioru tekstów, słuchanie warto traktować jako treść kształcenia polonistycznego, składową kompetencji komunikacyjnej. Proces doskonalenia (aktywizacji ${ }^{15}$ )

obcych. Red. A. Paliński. Wydawnictwo Wyższej Szkoły Pedagogicznej, Rzeszów 1982, s. 11-22; D. Kądzielawa: Czynność rozumienia mowy. Analiza neuropsychologiczna. Zakład Narodowy im. Ossolińskich, Wrocław 1983; W. Dobrołowicz: Badania nad recepcja informacji (ze szczególnym uwzględnieniem problemów uwagi). WSP, Kielce 1997; E. Dźwierzyńska: Antycypacja w procesie ksztattowania sprawności rozumienia mowy obcojęzycznej ze stuchu. Wydawnictwo Wyższej Szkoły Pedagogicznej, Rzeszów 2001; I. Kurcz: Psychologia języka i komunikacji...; M. McKay, M. Davis, P. Fanning: Sztuka skutecznego porozumiewania się. Przekł. A. Błaż. Wyd. 2. w jęz. pol. Gdańskie Wydawnictwo Psychologiczne, Gdańsk 2005; R.B. Adler, L.B. Rosenfeld, R.F. Proctor II: Relacje interpersonalne. Proces porozumiewania się. Współpr. N. Towne. Tłum. G. Skoczylas. Dom Wydawniczy Rebis, Poznań 2006; M. Dziewiecki: Psychologia porozumiewania się. Wydawnictwo Jedność, Kielce 2009; C.A. Roach, N.J. Wyatt: Stuchanie i proces retoryczny. Tłum. P. Kostyło. W: Mosty zamiast murów. Podręcznik komunikacji interpersonalnej. Red. J. Stewart. Wyd. 4., dodr. 3. Wydawnictwo Naukowe PWN, Warszawa 2009, s. 218-224; T. Wallace, W.E. Stariha, H.J. Walberg: Nauczanie sprawności mówienia, stuchania i pisania. Tłum. M. Lipińska-Derlikowska. W: Nauczanie w praktyce. Wybór i red. A. Janowski. T. 2. Ośrodek Rozwoju Edukacji, Warszawa 2010; A. Prizel-Kania: Rozwijanie sprawności rozumienia ze słuchu w języku polskim jako obcym. Księgarnia Akademicka, Kraków 2013.

${ }_{13}$ M.U. Chyb: Sprawności receptywno-produktywne w ksztatceniu sprawności stuchania. „Kształcenie Językowe” 2017, T. 15 (25), s. 31. https://doi.org/10.19195/1642-5782.15(25).3.

${ }_{14}$ R.S. Tomlin: Semantyka dyskursu. W: Dyskurs jako struktura i proces. Red. T.A. van Dijk. Przeł. G. Grochowski. Wydawnictwo Naukowe PWN, Warszawa 2001, s. 49. W niniejszym opracowaniu przez odbiór tekstu na poziomie lokalnym rozumiemy percepcję tekstu zarówno na poziomie epizodycznym, jak i lokalnym według Russella S. Tomlina.

${ }^{15}$ Por. M.U. Chyb: Aktywizowanie rozwoju sprawności stuchania w języku polskim jako ojczystym. „Z Teorii i Praktyki Dydaktycznej Języka Polskiego” 2020, T. 29, s. 157-171. https://doi.org/10.31261/TPDJP.2020.29.11. 
umiejętności słuchania jest długotrwały, powinien być wspierany na wszystkich etapach edukacyjnych i zmierzać do wyposażenia ucznia w niezbędne narzędzia pozwalające mu na odbiór różnego rodzaju tekstów w zróżnicowanych sytuacjach komunikacyjnych, aby w przyszłym życiu prywatnym i zawodowym uczeń był przygotowany do aktywnego uczestnictwa w komunikacji interpersonalnej i wykorzystania słuchania w celach poznawczych.

W nowej podstawie programowej języka polskiego dla szkoły podstawowej z 2017 roku nie znajdziemy jednak potwierdzenia konieczności wsparcia sprawności mówienia i słuchania w toku nauczania. W dokumencie tym w celach ogólnych zapisano jedynie, że lekcje języka polskiego mają służyć kształceniu ,umiejętności porozumiewania się (słuchania, czytania, mówienia i pisania) w różnych sytuacjach oficjalnych i nieoficjalnych, w tym także z osobami doświadczającymi trudności w komunikowaniu się"16. W wymaganiach szczegółowych jednak nie potwierdzono tego zapisu, odwołano się jedynie do odbioru tekstu w ogóle (nie wiadomo, czy pisanego czy słuchanego). Gdybyśmy przyjęli, że polonista wymagania szczegółowe ma realizować zarówno podczas czytania tekstów, jak i podczas ich słuchania, kształcenie percepcji słuchowej w szkole podstawowej mogłoby mieć na celu doskonalenie cząstkowych sprawności percepcyjnych (szczegółowo przedstawiłyśmy to w tabeli 1).

Tabela 1

Kształcenie umiejętności słuchania

w podstawie programowej języka polskiego z 2017 roku

\begin{tabular}{|c|c|}
\hline Klasy & Cząstkowe sprawności percepcyjne \\
\hline $\mathrm{IV}-\mathrm{VI}$ & \begin{tabular}{|l} 
identyfikacja typu komunikatu (II.3.1) \\
identyfikacja nadawcy i odbiorcy wypowiedzi (II.3.2) \\
określanie sytuacji komunikacyjnej i rozumienie jej wpływu na kształt wypo- \\
wiedzi (II.3.3)
\end{tabular} \\
\hline VII-VIII & \begin{tabular}{|l} 
rozróżnianie normy językowej wzorcowej oraz użytkowej (II.3.2) \\
rozpoznawanie i rozróżnianie środków perswazji i manipulacji w tekstach \\
reklamowych, określanie funkcji tych środków (III.1.8) \\
rozpoznawanie manipulacji językowej i przeciwstawianie jej zasady etyki wy- \\
powiedzi (III.1.9) \\
zgadzanie się z cudzymi poglądami lub polemizowanie z nimi, rzeczowe uza- \\
sadnianie własnego zdania (III.1.7)
\end{tabular} \\
\hline
\end{tabular}

Objaśnienia: W tabeli wymagania szczegółowe z podstawy programowej zostały sparafrazowane. W nawiasie podano odniesienia do zapisów podstawy programowej.

Źródło: Opracowano na podstawie: Podstawa programowa z komentarzem. Szkoła podstawowa. Język polski. Pobrano z: https://www.ore.edu.pl/wp-content/uploads/2018/03/podstawa-programowa-ksztalcenia-ogolnego-z-komentarzem.szkola-podstawowa-jezyk-polski.pdf [9.01.2021].

${ }^{16}$ Podstawa programowa z komentarzem. Szkoła podstawowa. Język polski. Pobrano z: https://www.ore.edu.pl/wp-content/uploads/2018/03/podstawa-programowa-ksztalcenia-ogolnego-z-komentarzem.-szkola-podstawowa-jezyk-polski.pdf [9.01.2021]. 
Model kształcenia umiejętności słuchania wyłaniający się z podstawy programowej nie jest zadowalający. W szkole podstawowej uczniowie, o ile nauczyciel się na to zdecyduje, doskonalą przede wszystkim wybrane receptywne sprawności językowe. Absolwent szkoły podstawowej powinien umieć rozpoznać sytuację komunikacyjną wypowiedzi, jej typ, ukształtowanie językowe, nadawcę i odbiorcę, a także opanować sprawność dostrzegania manipulacji i perswazji w słuchanych tekstach. Jedyną produktywną sprawnością komunikacyjną kształconą na tym etapie edukacji jest umiejętność polemizowania z nadawcą i wyrażania własnego zdania.

Można mieć zastrzeżenia do zapisów podstawy programowej, jeśli ma się wiedzę na temat specyfiki odbioru słuchowego. Nie ma w nich mowy o potrzebie doskonalenia funkcji poznawczych, warunkujących odbiór wypowiedzi, między innymi uwagi, koncentracji, pamięci słuchowej, selekcji i hierarchizacji informacji, wyciągania wniosków, umiejętności korzystania ze strategii pamięciowych. W podstawie nie zwraca się także uwagi na dźwiękową warstwę języka (jej analizę i interpretację), sprawność rozumienia wypowiedzi na poziomie lokalnym i globalnym. Autorzy nie dostrzegają konieczności opanowania przez uczniów rozumienia informacji przekazywanych w sposób pośredni, interpretowania ujętych $\mathrm{w}$ różne gatunki wypowiedzi w kontekstach społeczno-kulturowych. Absolwenci szkół podstawowych nie mają również możliwości wykonywania działań na słuchanych tekstach, a przede wszystkim nie są w stanie nabyć sprawności społeczno-komunikacyjnych. Można zatem uznać, że realizacja obecnych zapisów podstawy programowej nie gwarantuje uczniowi opanowania umiejętności słuchania.

\section{Sprawność mówienia}

Mówienie, podobnie jak słuchanie, jest złożoną umiejętnością komunikacyjną i nie sposób o nim mówić bez próby przedstawienia zależności między językiem, kompetencjami językową i komunikacyjną a wykonaniem.

Według Idy Kurcz podstawą działań językowych — w tym mówienia jest wiedza językowa, mająca wyraźny związek z nabywaniem i przyswajaniem doświadczeń językowych. Wiedza językowa obejmuje kompetencję językową oraz kompetencję komunikacyjną. Polega na

opanowaniu [...] wszelkich formalnych środków umożliwiających produkowanie i rozumienie zdań w tym języku, co za Chomskym określamy terminem kompetencja językowa, jak i na umiejętności tworzenia i odbierania tych zdań odpowiednio do sytuacji i do innych uczestników procesu 
komunikacji, co wymaga nieco innej wiedzy niż czysto językowa. Tę inną wiedzę określamy za Hymesem kompetencja komunikacyjna ${ }^{17}$.

W modelu wiedzy językowej oba rodzaje kompetencji są „równie niezbędne", ponieważ podstawę obu stanowią odmienne składniki ${ }^{18}$.

Wiedza językowa nie polega wyłącznie na umiejętności posługiwania się określonym językiem, musi pozostawać w jakichś relacjach z naszym obrazem świata, wiedzą o świecie, jaką ma każdy człowiek w formie reprezentacji umysłowej zakodowanej w pamięci długotrwałej. Wiedza językowa i wiedza o świecie są ściśle z sobą powiązane. Ta pierwsza odpowiedzialna jest za formalną stronę realizacji językowej, druga z kolei decyduje o tym, jaka będzie treść wykonania ${ }^{19}$ (rys. 1.).

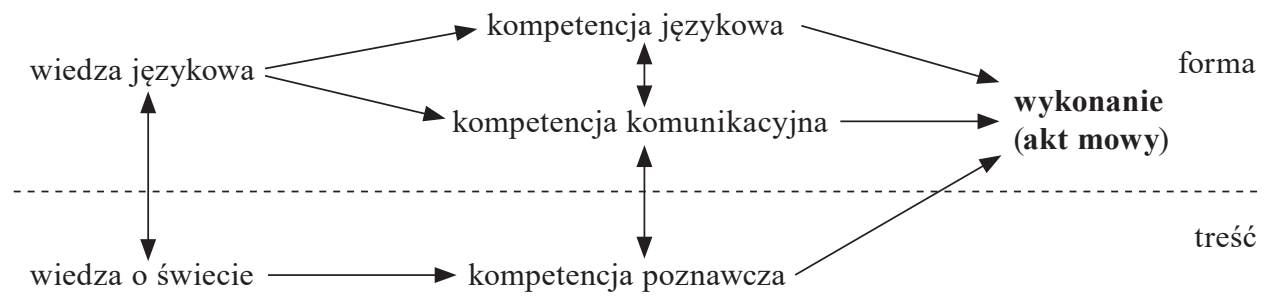

Rys. 1. Wykonanie (akt mowy) wedle koncepcji Idy Kurcz.

Źródło: Opracowano na podstawie: S. Frydrychowicz: Proces mówienia. Wybrane psychologiczne aspekty na przykładzie interpretacji zdania niejednoznacznego. Wydawnictwo Naukowe UAM, Poznań 1999 , s. 18.

Wiedzy o świecie odpowiada kompetencja poznawcza - uwarunkowane kulturowo zdolności intelektualne do klasyfikowania obiektów otaczającej rzeczywistości, umiejętność odczytywania zależności (na przykład związków przyczynowych) pomiędzy zjawiskami. Kompetencja poznawcza jest zatem sferą kulturowo regulowanych reakcji na zjawiska niosące informacje. Kompetencje językowa, komunikacyjna i poznawcza są ściśle z sobą powiązane, umożliwiają konkretne akty mowy (wykonania) ${ }^{20}$.

Podczas analizy konkretnych wypowiedzi mówionych należy wziąć pod uwagę nie tylko kod językowy, lecz także pozostałe dwa kody: parajęzyko-

${ }^{17}$ I. Kurcz: Pamięć, uczenie się, język. Wyd. 2. Wydawnictwo Naukowe PWN, Warszawa 1995, s. 213-214.

${ }^{18}$ I. Kurcz: Kompetencja językowa i kompetencja komunikacyjna: ich uwarunkowania biologiczne i społeczne. Model wiedzy językowej człowieka. W: Język jako przedmiot badań psychologicznych. Psycholingwistyka ogólna i neurolingwistyka. Red. I. Kurcz, H. Okuniewska. Wydawnictwo Szkoły Wyższej Psychologii Społecznej „Academica”, Warszawa 2011, s. 35—45.

${ }_{19}$ Więcej na temat strukturalnego modelu wiedzy o świecie w relacji do struktury wiedzy językowej zob. m.in. I. Kurcz: Pamięć, uczenie się, język..., s. 214.

20 S. Frydrychowicz: Proces mówienia. Wybrane psychologiczne aspekty na przykładzie interpretacji zdania niejednoznacznego. Wydawnictwo Naukowe UAM, Poznań 1999, s. 18. 
wy (prozodyczny: akcent, intonacja, rytm, oraz paraprozodyczny: ton głosu, brzmienie i tempo mówienia) i pozajęzykowy (przede wszystkim mimiczny i gestowy), które „modyfikują [...] znaczenie wypowiedzi słownych, ułatwiając lub utrudniając ich właściwe zrozumienie. Odgrywają też istotną rolę społeczną, kształtując nasze nastawienie do rozmówcy" ${ }^{21}$ oraz nastawienie rozmówców do nas.

Zapisy podstawy programowej wskazują, że mówienie (w przeciwieństwie do słuchania) jest jedną z istotniejszych sprawności rozwijanych w szkole. Waga tej sprawności podkreślona jest zarówno w Preambule: „Najważniejsze umiejętności rozwijane w ramach kształcenia ogólnego w szkole podstawowej to: 1) sprawne komunikowanie się w języku polskim" "22, jak i w wymaganiach ogólnych i szczegółowych ${ }^{23}$ (tabela 2).

Tabela 2

Sprawność mówienia w podstawie programowej języka polskiego z 2017 roku

\begin{tabular}{|c|c|}
\hline Klasy IV_-VI & Klasy VII_-VIII \\
\hline 1 & 2 \\
\hline \multicolumn{2}{|c|}{ Wymagania gólne } \\
\hline \multicolumn{2}{|c|}{$\begin{array}{l}\text { kształcenie umiejętności porozumiewania się (mówienia) w różnych sytuacjach komu- } \\
\text { nikacyjnych, również z osobami doświadczającymi trudności w komunikowaniu się* (II.4) } \\
\text { kształcenie umiejętności poprawnego mówienia zgodnego z zasadami ortofonii (II.5) } \\
\text { usprawnianie czynności fonacyjnych, artykulacyjnych i prozodycznych uczniów (III.1) } \\
\text { rozwijanie umiejętności wypowiadania się w określonych formach wypowiedzi ustnych } \\
\text { (III.2) } \\
\text { kształcenie umiejętności wygłaszania, recytacji i interpretacji głosowej tekstów mówio- } \\
\text { nych, doskonalenie dykcji i operowania głosem (III.3) }\end{array}$} \\
\hline \multicolumn{2}{|c|}{ Wymagania szczegółowe } \\
\hline $\begin{array}{l}\text { Uczeń: } \\
\text { posługuje się oficjalną i nieoficjalną od- } \\
\text { mianą polszczyzny (II.2.2) } \\
\text { używa stosownego stylu (II.2.3) } \\
\text { _ostosowuje sposób wyrażania się do celu } \\
\text { wypowiedzi (II.3.7) } \\
\text { stosuje w wypowiedziach synonimy i anto- } \\
\text { nimy (II.2.8) } \\
\text { rozpoznaje znaczenie niewerbalnych środ- } \\
\text { ków komunikacji (na przykład gest, mimi- } \\
\text { ka, postawa ciała) (II.3.4) } \\
\text { stosuje intonację poprawną ze względu na } \\
\text { cel wypowiedzi (II.3.6) }\end{array}$ & \begin{tabular}{|l} 
Uczeń: \\
rozumie, na czym polega grzeczność języ- \\
kowa, i stosuje ją w wypowiedziach (II.3.1) \\
stosuje się do norm językowych (II.3.2) \\
wykorzystuje środki retoryczne oraz rozu- \\
mie ich oddziaływanie (III.1.1) \\
porządkuje materiał rzeczowy potrzebny \\
do tworzenia wypowiedzi (III.1.2) \\
tworzy wypowiedź w odpowiednim gatun- \\
ku (III.1.3) \\
wykorzystuje znajomość zasad tworzenia \\
tezy, hipotezy przy tworzeniu tekstów argu- \\
mentacyjnych (III.1.4.)
\end{tabular} \\
\hline
\end{tabular}

${ }^{21}$ B.L.J. Kaczmarek: Misterne gry w komunikację. Wyd. 2. Wydawnictwo Uniwersytetu

Marii Curie-Skłodowskiej, Lublin 2009, s. 32.

${ }^{22}$ Podstawa programowa z komentarzem..., s. 5.

${ }^{23}$ Ibidem, s. 11-21. 
cd. tab. 2

\begin{tabular}{|c|c|}
\hline 1 & 2 \\
\hline $\begin{array}{l}\text { - stosuje zasady etykiety językowej w swojej } \\
\text { wypowiedzi (II.3.7) } \\
\text { _ uczestniczy w rozmowie (III.1.1) } \\
\text { _worzy logiczną, uporządkowaną i seman- } \\
\text { tycznie pełną wypowiedź (III.1.3) } \\
\text { _ tworzy spójną wypowiedź w danym gatun- } \\
\text { ku (III.2.1) } \\
\text { wygłasza z pamięci tekst z odpowiednią } \\
\text { intonacją, dykcją, właściwym akcentowa- } \\
\text { niem, odpowiednim napięciem emocjonal- } \\
\text { nym i następstwem pauz (III.2.2) }\end{array}$ & \begin{tabular}{|l} 
\\
- odróżnia przykład od argumentu (III.1.5) \\
wnioskuje (III.1.6) \\
potrafi zgadzać się z cudzymi poglądami \\
lub polemizować z nimi, rzeczowo uzasad- \\
nia własne zdania (III.1.7) \\
rozpoznaje manipulację językową i prze- \\
ciwstawia jej zasady etyki wypowiedzi \\
(III.1.9) \\
tworzy spójne wypowiedzi w wybranych \\
gatunkach (III.2.1) \\
przekształca teksty (III.2.2) \\
formułuje pytania (III.2.3) \\
dokonuje interpretacji głosowej czytanych \\
i wygłaszanych tekstów (III.2.4)
\end{tabular} \\
\hline
\end{tabular}

* Przywołany zapis podstawy programowej zachęca do postawienia pytania o rolę szkoły w usprawnianiu omawianych kompetencji między innymi u dzieci z ADHD, zaburzeniami mowy czy niepełnosprawnością ruchową. Treści dotyczą bowiem zarówno dzieci zdrowych, jak i dzieci z różnego rodzaju deficytami. W związku z tym może warto rozważyć na przykład stałą obecność logopedy w szkole lub rozszerzyć zakres zajęć z muzyki o rozwijanie umiejętności operowania głosem.

Objaśnienia: W tabeli wymagania szczegółowe z podstawy programowej zostały sparafrazowane. W nawiasach podano odniesienia do zapisów podstawy programowej.

Źródło: Opracowano na podstawie: Podstawa programowa z komentarzem. Szkoła podstawowa. Język polski. Pobrano z: https://www.ore.edu.pl/wp-content/uploads/2018/03/podstawa-programowa-ksztalcenia-ogolnego-z-komentarzem.szkola-podstawowa-jezyk-polski.pdf [9.01.2021].

Autorzy podstawy, uwzględniając takie aspekty, jak: merytoryczny, retoryczny, interakcyjny, kompozycyjny, stylowy, etykietalny, etyczny, językowy i niejęzykowy, dają ogólny obraz złożoności kategorii mówienia. Dopełnieniem tego obrazu mogą być zaproponowane przez Hannę Komorowską inne sprawności charakteryzujące użytkownika języka, między innymi: sprawność socjokulturowa, czyli znajomość faktów i norm kulturowych rządzących komunikacją w danym języku, wiedza, o czym wypada mówić, a o czym nie (częściowo zbieżna $\mathrm{z}$ aspektem etykietalnym); sprawność dyskursu językowego - ułatwiająca nawiązanie rozmowy, podtrzymanie jej i zakończenie; oraz sprawność strategiczna - pomagająca mówiącemu poradzić sobie z trudnościami komunikacyjnymi, jakie pojawiają się w rozmowie, a więc zasygnalizować niezrozumienie, poprosić rozmówcę o wyjaśnienie, powtórzenie itp. ${ }^{24}$

${ }^{24}$ H. Komorowska: Metodyka nauczania języków obcych. Fraszka Edukacyjna, Warszawa 2002, s. 12 . 


\section{Taksonomia sprawności słuchania i mówienia}

Pewnym ułatwieniem w wypracowaniu odpowiedniej metodyki kształcenia sprawności słuchania i mówienia mogłyby stać się odpowiednio przygotowane taksonomie tychże sprawności ${ }^{25}$; w taksonomiach tych wskazywano by na poziom i zakres kompetencji ucznia po szkole podstawowej. Warto podkreślić, iż propozycja ujęcia sprawności słuchania i mówienia w kategoriach taksonomicznych z jednej strony ma charakter porządkujący, systematyzujący i może być pomocna dla nauczyciela oraz ucznia w projektowaniu działań dydaktycznych, z drugiej strony zaś ograniczenie działań dydaktycznych do taksonomicznego paradygmatu jest niebezpieczne - zarówno dla nauczyciela, który może jawić się jedynie jako pośrednik, „wtórny nadawca” rozmaitych tekstów kultury, jak i dla ucznia działającego w ramach ustalonych procedur komunikacyjnych wyrażonych operatorami: wskaż, zanalizuj, zastosuj, oceńn ${ }^{26}$. Aktywizowanie postaw poznawczych narzędziami pomiaru taksonomicznego na wszystkich etapach kształcenia prowadzi do stereotypowego i w końcu bezrefleksyjnego powtarzania tych samych schematów działania, a w konsekwencji do zahamowania rozwoju kompetencji komunikacyjnej ${ }^{27}$. Słuchanie i mówienie to sprawności niezwykle złożone, które należy traktować w sposób holistyczny, integralny. Wprawdzie można wyróżnić ich elementy składowe, ale trzeba pamiętać, że „,analityczne części nie sumują się do całości, przy czym relacje między nimi są skomplikowane, wieloaspektowe i wykraczają poza prostą kolekcję cech" 28 .

\section{Taksonomia sprawności słuchania}

Podstawa programowa nie może stanowić pomocy dla polonisty dostrzegającego potrzebę doskonalenia percepcji słuchowej na lekcjach języka ojczystego, proponujemy więc autorską taksonomię sprawności słuchania, inspirowaną koncepcją Tadeusza Patrzałka przedstawioną w artykule $O$ strukturze testu czytania ze zrozumieniem z 1998 roku $^{29}$.

${ }^{25}$ Oczywiście jest to projekt wymagający dyskusji, na temat taksonomii zob. T. Patrzałek: O strukturze testu czytania ze zrozumieniem. „Polonistyka” 1998, nr 4, s. 202-207.

${ }_{26}$ T. Półchłopek: Pomiar dydaktyczny w procesie organizacji pracy nauczyciela. „Zeszyty Naukowe Uniwersytetu Rzeszowskiego. Seria Filologiczna. Dydaktyka” 2012, z. 7 (72), s. 184.

27 T. Patrzałek: O strukturze testu czytania ze zrozumieniem...

28 J. Nocoń: Diagnozowanie sprawności mówienia..., s. 8.

${ }_{29}$ Zob. T. Patrzałek: O strukturze testu czytania ze zrozumieniem... Założenia autora dostosowałyśmy do specyfiki słuchowego odbioru wypowiedzi. 
Przyjmujemy, że sprawność słuchania może być ujęta w cztery kategorie taksonomiczne:

A. Odtwarzanie - elementarne rozumienie wypowiedzi na poziomie dosłownym, zapamiętywanie i przytaczanie usłyszanych informacji.

B. Przetwarzanie - rozumienie wypowiedzi na poziomie interpretacyjnym, przetwarzanie usłyszanych informacji.

C. Wykorzystanie - wykorzystanie wypowiedzi i zawartych w niej szczegółowych informacji do realizacji własnych celów, na przykład wykonywania działań na słuchanych tekstach, tworzenia innych tekstów (mówionych lub pisanych), uzasadnienia swojego stanowiska, oceny słuchanego tekstu.

D. Uczestniczenie - aktywny udział w komunikacji z drugim człowiekiem, reagowanie na komunikaty ze świadomością ich funkcji i efektów komunikacyjnych, słuchanie empatyczne i życzliwe, przekazywanie usłyszanych informacji partnerowi komunikacyjnemu.

Kategorie A i B obejmują wyłącznie sprawności receptywne, warunkujące rozumienie wypowiedzi zarówno na poziomie globalnym, jak i lokalnym. Z kolei do kategorii C i D zostały przypisane sprawności produktywne: uczeń słucha tekstu i wykorzystuje zdobyte informacje do realizacji celów poznawczych (kategoria C) bądź świadomego uczestnictwa w komunikacji z drugim człowiekiem (kategoria D).

Sprawności percepcyjne $\mathrm{z}$ trzech pierwszych kategorii taksonomicznych (A, B, C) podzieliłyśmy ze względu na poziom odbioru tekstu na sprawności odnoszące się do poziomu globalnego i lokalnego wypowiedzi. Natomiast przy wyróżnianiu sprawności składających się na kategorię D (uczestniczenie) zrezygnowałyśmy z tego podziału, uznałyśmy bowiem, że w naturalnej komunikacji dwa poziomy odbioru tekstu są niemożliwe do rozdzielenia.

Taksonomię umiejętności słuchania przedstawiłyśmy w tabeli $3^{30}$.

Jeżeli spojrzymy na zapisy podstawy programowej (tabela 1) z perspektywy zaproponowanej taksonomii sprawności słuchania, możemy dojść do wniosku, że na lekcjach języka polskiego uczniowie mają doskonalić jedynie wybrane (wedle jakiegoś niewiadomego kryterium) sprawności z kategorii B (przetwarzanie). Natomiast w podstawie nie ma mowy o doskonaleniu bardziej zaawansowanych sprawności warunkujących efektywny odbiór różnego rodzaju tekstów w celach poznawczych i komunikacyjnych, więc prawdopodobnie sprawności tego typu nie są rozwijane na lekcjach języka polskiego.

${ }^{30}$ Wykaz sprawności nie jest zamknięty i powinien być rozszerzany o inne sprawności, odpowiadające na potrzeby współczesności. 
Tabela 3

Taksonomia sprawności słuchania — propozycja autorska

\begin{tabular}{|c|c|c|}
\hline \multirow{2}{*}{$\begin{array}{c}\text { Kategoria } \\
\text { taksono- } \\
\text { miczna }\end{array}$} & \multicolumn{2}{|c|}{ Poziom odbioru tekstu } \\
\hline & globalny & lokalny \\
\hline 1 & 2 & 3 \\
\hline \multicolumn{3}{|c|}{ Sprawności receptywne } \\
\hline 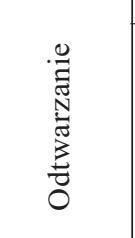 & $\begin{array}{l}\text { odtwarzanie tematu, funkcji, celu teks- } \\
\text { tu sformułowanych dosłownie lub za- } \\
\text { sygnalizowanych }\end{array}$ & $\begin{array}{l}\text { odnajdywanie gotowych infor- } \\
\text { macji z tekstu, sądów, opinii sformu- } \\
\text { łowanych dosłownie lub zasygnali- } \\
\text { zowanych } \\
\text { porządkowanie usłyszanych infor- } \\
\text { macji }\end{array}$ \\
\hline 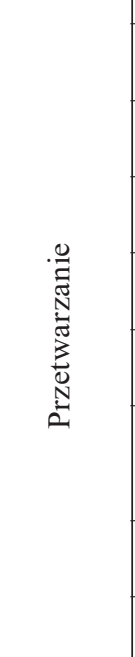 & $\begin{array}{l}\text { - określanie głównej myśli, przesłania, } \\
\text { intencji tekstu } \\
\text { rozpoznawanie dominanty treściowej } \\
\text { tekstu } \\
\text { określanie gatunku i funkcji wypowie- } \\
\text { dzi } \\
\text { identyfikowanie aktów mowy (na przy- } \\
\text { kład życzenia, gratulacje, pożegnanie) } \\
\text { określanie sytuacji mówienia (nadaw- } \\
\text { cy, odbiorcy, relacji między nimi) } \\
\text { identyfikowanie perspektywy, punktu } \\
\text { widzenia nadawcy, jego emocji, na- } \\
\text { stroju } \\
\text { rekonstrukcja toku rozumowania na- } \\
\text { dawcy } \\
\text { interpretacja dźwiękowej warstwy ko- } \\
\text { munikatu, określanie jej funkcji }\end{array}$ & $\begin{array}{l}\text { porządkowanie usłyszanych infor- } \\
\text { macji według wybranych lub zada- } \\
\text { nych kryteriów } \\
\text { _ wskazywanie przyczyn i skutków } \\
\text { _ oddzielanie informacji od opinii } \\
\text { _ozróżnianie odpowiedzi właści- } \\
\text { wych i unikowych, pytań podchwyt- } \\
\text { liwych i sugerujących odpowiedź, } \\
\text { argumentu i przykładu } \\
\text { formułowanie wniosków na podsta- } \\
\text { wie usłyszanych informacji }\end{array}$ \\
\hline \multicolumn{3}{|c|}{ Sprawności produktywne } \\
\hline 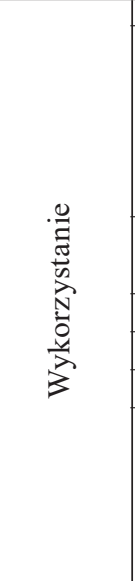 & $\begin{array}{l}\text { - krytyczny odbiór wypowiedzi: oce- } \\
\text { nianie i uzasadnianie prawdomówno- } \\
\text { ści, intencji autora, wartości etycznych } \\
\text { i estetycznych tekstów, ocenianie celo- } \\
\text { wości użycia środków językowych } \\
\text { ocenianie i wartościowanie subiek- } \\
\text { tywnych doświadczeń słuchowych } \\
\text { - nadawanie tytułu tekstowi } \\
\text { - skracanie tekstu } \\
\text { - zadawanie pytań do tekstu } \\
\text { odnoszenie przesłania tekstu do spo- } \\
\text { łecznej sytuacji komunikacyjnej i in- } \\
\text { dywidualnej sytuacji z życia }\end{array}$ & $\begin{array}{l}\text { - wykonywanie działań na tekstach } \\
\text { mówionych (na przykład wybór słów } \\
\text { kluczowych, redagowanie planu od- } \\
\text { twórczego, dokonywanie ekscerptu) } \\
\text { notowanie informacji w różnych ce- } \\
\text { lach } \\
\text { _ przepisywanie tekstów ze słuchu } \\
\text { _ostrzeganie i poprawianie błędów } \\
\text { językowych w wypowiedziach } \\
\text { porównywanie z sobą informacji } \\
\text { zawartych w tekstach mówionych, } \\
\text { audialnych i audiowizualnych (także } \\
\text { w tekstach pisanych) } \\
\text { wartościowanie informacji z teks- } \\
\text { tu w kontekście pozatekstowym }\end{array}$ \\
\hline
\end{tabular}


cd. tab. 3

\begin{tabular}{|c|c|c|}
\hline 1 & 2 & 3 \\
\hline $\begin{array}{l}\stackrel{0}{\Xi} \\
\tilde{N} \\
.0 \\
\tilde{N} \\
0 \\
\tilde{N} \\
0 \\
D\end{array}$ & $\begin{array}{l}\text { - słuchanie partnera } \\
\text { giego człowieka, } \\
\text { umiejętne (zgodne } \\
\text { szane komunikaty } \\
\text { nakłanianie nada } \\
\text { frazowanie wypov } \\
\text { - porównywanie po } \\
\text { - precyzyjne wyraż } \\
\text { - przekazywanie us }\end{array}$ & $\begin{array}{l}\text { oycie otwartym na dru- } \\
\text { dania myśli } \\
\text { ej) reagowanie na usły- } \\
\text { ych, rozstrzygających), } \\
\text { rmułowanie rad, para- } \\
\text { umiałych kwestii } \\
\text { iami } \\
\text { ilkacyjnemu }\end{array}$ \\
\hline
\end{tabular}

W języku polskim jako ojczystym uczniowie zapewne z łatwością rozumieją na poziomie dosłownym wypowiedzi z różnych sfer życia, takie, w których poruszono tematy złożone, abstrakcyjne, wcześniej uczniom nieznane, także komunikaty artykułowane niewyraźnie, w szybkim tempie; na jakość odbioru przekazów nie wpływają przeszkody, takie jak redundancja, efekt słuchowy, hałas (szum), nakładanie się dźwięków, zakłócenia itp. ${ }^{31}$ Można postawić tezę, że lekcje języka polskiego powinny służyć rozwojowi sprawności z kategorii B, C i D. Rozwój sprawności związanych z odtwarzaniem wypowiedzi i zawartych w nich informacji (kategoria A) może być jedynie funkcjonalny w pracy z młodszymi dziećmi (edukacja przedszkolna i wczesnoszkolna). Jej celem jest doskonalenie uwagi, koncentracji na słuchanym tekście, pamięci słuchowej i selekcji informacji. Kształcenie sprawności z kategorii A można traktować jedynie jako „wprawki” w słuchaniu, ćwiczenia przygotowujące do kompetentnego odbioru wypowiedzi oraz pracy z nią. Aby doskonalenie słuchania było funkcjonalne, uczniowie powinni jak najczęściej mieć możliwość wykorzystywania słuchanych tekstów do realizacji założonych przez siebie celów (kategoria C) i uczestniczenia w rzeczywistych aktach komunikacji $\left(\right.$ kategoria $\mathrm{D}^{32}$ ).

\section{Taksonomia sprawności mówienia}

W naszej propozycji taksonomii sprawności mówienia również dzielimy je na cztery kategorie:

${ }^{31}$ Por. Europejski system opisu ksztatcenia językowego: uczenie sie, nauczanie, ocenianie. Tłum. W. Martyniuk. Council of Europe-Wydawnictwa Centralnego Ośrodka Doskonalenia Nauczycieli, Warszawa 2003.

${ }^{32}$ Kształcenie sprawności w kategorii D stanowi naturalne przejście do kształcenia innych sprawności komunikacyjnych: mówienia, pisania i czytania. Por. H. Komorowska: Metodyka nauczania języków obcych..., s. 184-185; E. Gajewska: Techniki nauczania języka obcego. Adaptacja poleceń w jęz. ang. D. Ruszkiewicz. Adaptacja poleceń w jęz. niem. M. Stypińska. Państwowa Wyższa Szkoła Zawodowa, Tarnów 2011, s. 76. 
A. Odtwarzanie - ustne odtwarzanie czy powtarzanie gotowych informacji, sądów, opinii itp.

B. Przetwarzanie - ustne przetwarzanie informacji, sądów, opinii; ustne operowanie tekstem i zawartą w nim informacją.

C. Stosowanie - twórcze wykorzystanie informacji w praktyce ustnej.

D. Uczestniczenie - aktywny udział w komunikacji z drugim człowiekiem.

Zaproponowane przez Patrzałka wartościowanie przypisałyśmy kategorii C - stosowaniu. Uznałyśmy bowiem, że krytyczny odbiór komunikatu, czyli ustne ocenianie i uzasadnianie intencji, prawdomówności autora komunikatu, współrozmówcy, wartościowanie tekstów pod kątem etycznym i estetycznym, ocenianie celowości użycia środków językowych i niejęzykowych ${ }^{33}$, to umiejętności polegające na wykorzystaniu informacji w celu tworzenia wypowiedzi (monologowych bądź dialogowych) dotyczących zagadnień etycznych i estetycznych. Kategorią odpowiadającą rzeczywistemu kształtowaniu postawy i wychowaniu językowemu jest kategoria $\mathrm{D}$, czyli aktywny udział w komunikacji świadczący o otwarciu na drugiego człowieka.

Istotne jest również to, by na sprawność mówienia spojrzeć z perspektywy trzech podstawowych kodów: językowego, parajęzykowego i pozajęzykowego. Ujęcie ich w taksonomii może wpłynąć na bardziej świadome i celowe stosowanie komunikacji niejęzykowej. Efektywność komunikacji wzrasta bowiem wraz ze zwiększaniem się spójności stosowanych sygnałów językowych, parajęzykowych i pozajęzykowych (tabela 4).

Tabela 4

Taksonomia sprawności mówienia — propozycja autorska

\begin{tabular}{|c|c|c|c|c|}
\hline \multirow{3}{*}{$\begin{array}{l}\text { Katego- } \\
\text { ria } \\
\text { taksono- } \\
\text { miczna }\end{array}$} & \multirow{3}{*}{ Operatory } & \multicolumn{3}{|c|}{ Kod } \\
\hline & & \multirow{2}{*}{ językowy } & \multicolumn{2}{|l|}{ niejęzykowy } \\
\hline & & & parajęzykowy & pozajęzykowy \\
\hline 1 & 2 & 3 & 4 & 5 \\
\hline 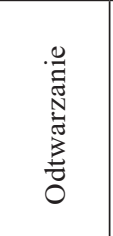 & $\begin{array}{l}\text { powtarzam, odtwarzam } \\
\text { (na przykład tekst, gest } \\
\text { dźwięk) }\end{array}$ & $\begin{array}{l}\text { ustne odtwarzanie } \\
\text { gotowych informacji, } \\
\text { sądów, opinii itp. }\end{array}$ & 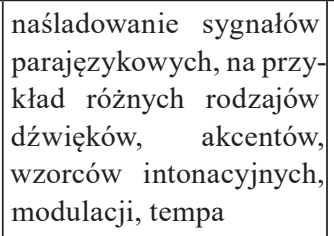 & $\begin{array}{l}\text { na śla dowa- } \\
\text { nie sygnałów } \\
\text { ciała (mimi- } \\
\text { ki, gestów, po- } \\
\text { stawy itp.) }\end{array}$ \\
\hline 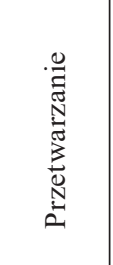 & $\begin{array}{l}\text { wyjaśniam, tłumaczę, } \\
\text { przedstawiam innymi sło- } \\
\text { wami, opowiadam, opisu- } \\
\text { ję, prezentuję na podsta- } \\
\text { wie tekstu czy własnych } \\
\text { doświadczeń, zadaję py- } \\
\text { tanie do tekstu itp. }\end{array}$ & $\begin{array}{l}\text { ustne, zgodne } z \text { nor- } \\
\text { mą przetwarzanie in- } \\
\text { formacji, sądów, opi- } \\
\text { nii; operowanie teks- } \\
\text { tem i zawartą w nim } \\
\text { informacją }\end{array}$ & $\begin{array}{l}\text { posługiwanie się sygna- } \\
\text { łami parajęzykowymi, } \\
\text { między innymi akcen- } \\
\text { tem, wzorcami intona- } \\
\text { cyjnymi, modulacją, tem- } \\
\text { pem, pauzą, frazą itp. }\end{array}$ & $\begin{array}{l}\text { posługiwa- } \\
\text { nie się syg- } \\
\text { nałami ciała } \\
\text { (mimiką, ge- } \\
\text { stem, posta- } \\
\text { wą ciała) }\end{array}$ \\
\hline
\end{tabular}

${ }^{33}$ T. Patrzałek: O strukturze testu czytania ze zrozumieniem... 
cd. tab. 4

\begin{tabular}{|c|c|c|c|c|}
\hline 1 & 2 & 3 & 4 & 5 \\
\hline 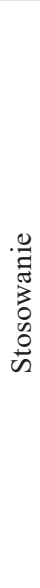 & $\begin{array}{l}\text { wypowiadam się (na te- } \\
\text { mat przygotowany wcześ- } \\
\text { niej, spontanicznie, płyn- } \\
\text { nie), przekonuję, uzasad- } \\
\text { niam, rozmawiam, dysku- } \\
\text { tuję, oceniam, wyrażam } \\
\text { opinię, pytam, świadomie } \\
\text { i celowo wykorzystuję } \\
\text { środki niejęzykowe itp. }\end{array}$ & $\begin{array}{l}\text { wykorzystanie infor- } \\
\text { macji w praktyce } \\
\text { zgodnie znormą, spon- } \\
\text { taniczne bądź przygo- } \\
\text { towanereakcjesłowne, } \\
\text { dyskutowanie, porozu- } \\
\text { miewanie się, tworze- } \\
\text { nie ustnej wypowie- } \\
\text { dzi monologowej, uza- } \\
\text { sadnianie, wnioskowa- } \\
\text { nie, ustne wyrażanie } \\
\text { opinii na dany temat, } \\
\text { krytyczny odbiór teks- } \\
\text { tu kultury, na przy- } \\
\text { kład jego estetyki }\end{array}$ & $\begin{array}{l}\text { świadome i celowe* po- } \\
\text { sługiwanie się sygnałami } \\
\text { parajęzykowymi, mię- } \\
\text { dzy innymi akcentem, } \\
\text { wzorcami intonacyjny- } \\
\text { mi, modulacją, tempem, } \\
\text { pauzą, frazą itp. }\end{array}$ & $\begin{array}{l}\text { ś w i d o me } \\
\text { i celowe po- } \\
\text { sługiwanie } \\
\text { się sygnała- } \\
\text { mi ciała (mi- } \\
\text { miką, gestem, } \\
\text { postawą cia- } \\
\text { ła) }\end{array}$ \\
\hline \multirow{6}{*}{ 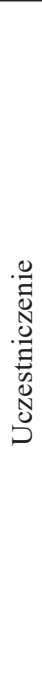 } & \multirow{6}{*}{$\begin{array}{l}\text { chcę i komunikuję się, } \\
\text { chcę się porozumieć, } \\
\text { stosuję zasady racjonal- } \\
\text { nej dyskusji, właściwie } \\
\text { reaguję na komunikaty, } \\
\text { unikam nieporozumien,, } \\
\text { buduję wypowiedzi jasne, } \\
\text { rzetelne, stosowne i jed- } \\
\text { noznaczne, świadomie } \\
\text { i celowo stosuję sygnały } \\
\text { niejęzykowe itp. }\end{array}$} & \multicolumn{3}{|c|}{$\begin{array}{l}\text { porozumiewanie się z drugim człowiekiem z uwzględnieniem } \\
\text { zasad szacunku, autonomii i empatii - na zasadzie pewnej } \\
\text { umowy zobowiązującej rozmówców do wykazywania dobrej } \\
\text { woli, wzajemnej pomocy w trakcie wspólnego działania }\end{array}$} \\
\hline & & \multicolumn{3}{|c|}{$\begin{array}{l}\text { stosowanie podczas dyskusji zasad: równych praw, odpowie- } \\
\text { dzialności, uczciwości, relewancji, konsensusu** }\end{array}$} \\
\hline & & \multicolumn{3}{|c|}{$\begin{array}{l}\text { właściwe — zgodne z etyką i zasadami grzeczności języko- } \\
\text { wej — reagowanie na usłyszane komunikaty }\end{array}$} \\
\hline & & \multicolumn{3}{|c|}{$\begin{array}{l}\text { unikanie nieporozumień komunikacyjnych poprzez na przy- } \\
\text { kład proszenie o wyjaśnienie niezrozumiałych kwestii, powtó- } \\
\text { rzenie wypowiedzi — radzenie sobie z trudnościami komuni- } \\
\text { kacyjnymi, dążenie do porozumienia }\end{array}$} \\
\hline & & \multicolumn{3}{|c|}{$\begin{array}{l}\text { budowanie stosownych, jasnych, rzetelnych, jednoznacznych } \\
\text { wypowiedzi }\end{array}$} \\
\hline & & \multicolumn{3}{|c|}{$\begin{array}{l}\text { stosowanie sygnałów niejęzykowych potwierdzających, } \\
\text { wzmacniających komunikaty językowe }\end{array}$} \\
\hline
\end{tabular}

" Przez uwzględnienie w kategorii C celowości i świadomości w posługiwaniu się sygnałami para- i pozajęzykowymi chcemy podkreślić, że uczeń dokonuje wyboru środków niejęzykowych pod kątem swoich potrzeb komunikacyjnych.

** Na temat racjonalnej dyskusji zob. m.in. T. Hołówka: Zasady dyskusji racjonalnej. W: Etyka międzyludzkiej komunikacji. Red. J. Puzynina. Wydawnictwo Naukowe Semper, Warszawa 1993, s. 24-26.

Rozpatrywanie zapisów podstawy programowej (tabela 2) z perspektywy zaproponowanej taksonomii mówienia pozwala na stwierdzenie, że na lekcjach języka polskiego uczeń ma szansę doskonalić szereg sprawności z wszystkich kategorii. Jednak gdy nauczyciel jest dominujący, a wiodący sposób komunikowania się na lekcji charakteryzuje się między innymi jednokierunkowością, brakiem spontaniczności, specyficznym zestawem aktów 
mowy ${ }^{34}$ (w którym pytanie odgrywa kluczową rolę, a dodajmy, że najczęściej jest to pytanie niższego $\mathrm{rzędu}^{35}$ ), to mimo iż w dokumencie zapisy dotyczące tej sprawności produktywnej są dość obszerne, uczeń nie ma zbyt wielu okazji i szans do rozwijania mówienia. Natomiast sprawności z kategorii D, które uznajemy za jedne z najistotniejszych, właściwie wcale nie są rozwijane.

Propozycja taksonomii sprawności mówienia i słuchania, którą przedstawiłyśmy, wymaga dopracowania, mamy jednak nadzieję, że czytelnicy, zwłaszcza nauczyciele języka polskiego, którzy dostrzegają potrzebę systematycznego, celowego doskonalenia słuchania i mówienia, wykorzystają zgormadzony w tym artykule materiał do opracowania autorskiego programu kształcenia tych sprawności w szkole podstawowej. Być może nasza koncepcja zainspiruje dydaktyków do opracowania metodyki kształcenia sprawności mówienia i słuchania w języku polskim jako ojczystym.

\section{Bibliografia}

Adler R.B., Rosenfeld L.B., Proctor II R.F.: Relacje interpersonalne. Proces porozumiewania się. Współpr. N. Towne. Tłum. G. Skoczylas. Dom Wydawniczy Rebis, Poznań 2006.

Bakuła K.: Mówione z pisane: komunikacja, język, tekst. Wydawnictwo Uniwersytetu Wrocławskiego, Wrocław 2008.

Chyb M.: Efektywne stuchanie w języku polskim jako ojczystym - diagnoza i profilaktyka. Praca doktorska pod kierunkiem J. Nocoń. Uniwersytet Opolski. Opole 2021 [maszynopis niepublikowany].

Chyb M.U.: Aktywizowanie rozwoju sprawności stuchania w języku polskim jako ojczystym. „Z Teorii i Praktyki Dydaktycznej Języka Polskiego" 2020, T. 29, s. 157-171. https://doi. org/10.31261/TPDJP.2020.29.11.

Chyb M.U.: Jak stucha ósmoklasista? Próba diagnozy [w druku].

Chyb M.U.: Sprawności receptywno-produktywne w kształceniu sprawności słuchania. „Kształcenie Językowe" 2017, T. 15 (25), s. 27-39. https://doi.org/10.19195/1642-5782.15(25).3.

Chyb M.U.: Umiejętność stuchania czwartoklasistów. Próba diagnozy. „Kształcenie Językowe” 2020, T. 18 (28), s. 39-61. https://doi.org/10.19195/1642-5782.18(28).4.

Dobrołowicz W.: Badania nad recepcja informacji (ze szczególnym uwzględnieniem problemów uwagi). WSP, Kielce 1997.

Dziewiecki M.: Psychologia porozumiewania się. Wydawnictwo Jedność, Kielce 2009.

${ }^{34}$ J. Nocoń: Stylistyczne aspekty dyskursu edukacyjnego. W: Odmiany stylowe polszczyz-

ny - dawniej i dziś. Red. U. Sokólska. Wydawnictwo Uniwersytetu w Białymstoku, Białystok 2011, s. 196.

${ }^{35}$ Zob. E. Perrott: Efektywne nauczanie. Praktyczny przewodnik doskonalenia nauczania. Tłum. A. Janowski. Wydawnictwa Szkolne i Pedagogiczne, Warszawa 1995, s. 44-55. 
Dźwierzyńska E.: Antycypacja w procesie ksztattowania sprawności rozumienia mowy obcojęzycznej ze stuchu. Wydawnictwo Wyższej Szkoły Pedagogicznej, Rzeszów 2001.

Europejski system opisu ksztatcenia językowego: uczenie się, nauczanie, ocenianie. Council of Europe-Wydawnictwa Centralnego Ośrodka Doskonalenia Nauczycieli, Warszawa 2003.

Frydrychowicz S.: Proces mówienia. Wybrane psychologiczne aspekty na przyktadzie interpretacji zdania niejednoznacznego. Wydawnictwo Naukowe UAM, Poznań 1999.

Gajewska E.: Techniki nauczania języka obcego. Adaptacja poleceń w jęz. ang. D. Ruszkiewicz. Adaptacja poleceń w jęz. niem. M. Stypińska. Państwowa Wyższa Szkoła Zawodowa, Tarnów 2011.

Giddens A.: Socjologia. Wyd. 1., dodruk. Tłum. A. Szulżycka. Wydawnictwo Naukowe PWN, Warszawa 2004.

[Hasło:] predyspozycja. https://wsjp.pl/index.php?id_hasla=4874 [dostęp: 9.01.2021].

Hołówka T.: Zasady dyskusji racjonalnej. W: Etyka międzyludzkiej komunikacji. Red. J. Puzynina. Wydawnictwo Naukowe Semper, Warszawa 1993, s. 24-26.

Kaczmarek B.L.J.: Misterne gry w komunikację. Wyd. 2. Wydawnictwo Uniwersytetu Marii Curie-Skłodowskiej, Lublin 2009.

Kądzielawa D.: Czynność rozumienia mowy. Analiza neuropsychologiczna. Zakład Narodowy im. Ossolińskich, Wrocław 1983.

Klus-Stańska D., Nowicka M.: Sensy i bezsensy edukacji wczesnoszkolnej. Harmonia Universalis, Gdańsk 2014.

Komorowska H.: Metodyka nauczania języków obcych. Fraszka Edukacyjna, Warszawa 2002.

Kurcz I.: Kompetencja językowa i kompetencja komunikacyjna: ich uwarunkowania biologiczne i społeczne. Model wiedzy językowej człowieka. W: Język jako przedmiot badań psychologicznych. Psycholingwistyka ogólna i neurolingwistyka. Red. I. Kurcz, H. Okuniewska. Wydawnictwo Szkoły Wyższej Psychologii Społecznej „Academica”, Warszawa 2011, s. 35-45.

Kurcz I.: Pamięć, uczenie się, język. Wyd. 2. Wydawnictwo Naukowe PWN, Warszawa 1995.

Kurcz I.: Psychologia języka i komunikacji. Wyd. 2., nowe. Scholar, Warszawa 2005.

McKay M., Davis M., Fanning P.: Sztuka skutecznego porozumiewania się. Przekł. A. Błaż. Wyd. 2., w jęz. pol. Gdańskie Wydawnictwo Psychologiczne, Gdańsk 2005.

Nocoń J.: Diagnozowanie sprawności mówienia w perspektywie (nie tylko) egzaminu maturalnego. „Polonistyka. Innowacje” 2015, nr 1, s. 4-15. https://doi.org/10.14746/pi.2015.1.1.1.

Nocoń J.: Stylistyczne aspekty dyskursu edukacyjnego. W: Odmiany stylowe polszczyzny - dawniej $i$ dziś. Red. U. Sokólska. Wydawnictwo Uniwersytetu w Białymstoku, Białystok 2011, s. $187-200$.

Paliński A.: Psychologiczna charakterystyka procesów stuchania i czytania w języku obcym w aspekcie porównawczym. W: Sprawność stuchania i czytania w nauczaniu języków obcych. Red. A. Paliński. Wydawnictwo Wyższej Szkoły Pedagogicznej, Rzeszów 1982, s. 11—22.

Patrzałek T.: O strukturze testu czytania ze zrozumieniem. „Polonistyka” 1998, nr 4, s. 202-207.

Perrott E.: Efektywne nauczanie. Praktyczny przewodnik doskonalenia nauczania. Tłum. A. Janowski. Wydawnictwa Szkolne i Pedagogiczne, Warszawa 1995.

Podstawa programowa z komentarzem. Szkoła podstawowa. Język polski. Pobrano z: https:// www.ore.edu.pl/wp-content/uploads/2018/03/podstawa-programowa-ksztalcenia-ogolnego-zkomentarzem.-szkola-podstawowa-jezyk-polski.pdf [9.01.2021].

„Polonistyka. Innowacje” 2015, nr 1. https://pressto.amu.edu.pl/index.php/pi/issue/view/110 [dostęp: 2.12.2020].

Półchłopek T.: Pomiar dydaktyczny $w$ procesie organizacji pracy nauczyciela. „Zeszyty Naukowe Uniwersytetu Rzeszowskiego. Seria Filologiczna. Dydaktyka” 2012, z. 7 (72), s. 179-187.

Prizel-Kania A.: Rozwijanie sprawności rozumienia ze stuchu w języku polskim jako obcym. Księgarnia Akademicka, Kraków 2013. 
Roach C.A., Wyatt N.J.: Stuchanie i proces retoryczny. Tłum. P. Kostyło. W: Mosty zamiast murów. Podręcznik komunikacji interpersonalnej. Red. J. Stewart. Wyd. 4., dodr. 3. Wydawnictwo Naukowe PWN, Warszawa 2009, s. 218-224.

Sękowski A.E., Bilyakovska O.: Zdolności czlowieka jako wymiar psychologiczny. „Języki Obce w Szkole" 2011, nr 1, s. 18-24.

Tabisz A.: Czy szkoła uczy mówienia? O ustnych wypowiedziach gimnazjalistów. „Polonistyka. Innowacje" 2015, nr 1, s. 54-69. https://doi.org/10.14746/pi.2015.1.1.5.

Tabisz A.: Czy zmierzch kultury mówienia? - o wybranych cechach ustnych wypowiedzi maturzystów. W: Istnieć w kulturze, istnieć w kulturach: między teoria a praktyka edukacyjna. Red. A. Rypel, D. Jastrzębska-Golonka. Wydawnictwo Uniwersytetu Kazimierza Wielkiego, Bydgoszcz 2018, s. 186-202.

Tabisz A.: Lekcje mówienia - o (nie)płynności wypowiedzi. W: Uczenie języka ojczystego w czasach ponowoczesnych. Red. A. Tabisz. [Język a Edukacja, 5]. Wydawnictwo Uniwersytetu Opolskiego, Opole 2017, s. 253-264.

Tomlin R.S.: Semantyka dyskursu. W: Dyskurs jako struktura i proces. Red. T.A. van Dijk. Przeł. G. Grochowski. Wydawnictwo Naukowe PWN, Warszawa 2001, s. 45-101.

Wallace T., Stariha W.E., Walberg H.J.: Nauczanie sprawności mówienia, stuchania i pisania. Thum. M. Lipińska-Derlikowska. W: Nauczanie w praktyce. Wybór i red. A. Janowski. T. 2. Ośrodek Rozwoju Edukacji, Warszawa 2010. 